\title{
DEFENDING INDONESIA'S PULP AND PAPER INDUSTRY: A REVIEW ON CORPORATE RESPONSIBILITY COMMUNICATIONS
}

\author{
Ligia Santosa \\ Center for Pulp and Paper, Bandung 40258, West Java-Indonesia \\ ligiagara@yahoo.com
}

Diterima : 02 April 2013, Revisi akhir : 16 Mei 2013, Disetujui terbit : 30 Mei 2013

\author{
PERLINDUNGAN INDUSTRI PULP DAN KERTAS INDONESIA: SEBUAH \\ TINJAUAN KOMUNIKASI TANGGUNG JAWAB SOSIAL PERUSAHAAN
}

\begin{abstract}
ABSTRAK
Industri hasil hutan Indonesia didominasi oleh pulp dan kertas dengan $60 \%$ dari keluaran total sebesar US\$ 7 milyar dalam ekspor pada tahun 2010. Jumlah tersebut merepresentasikan 4\% dari total ekspor negara dan menyediakan penghidupan bagi 15 juta orang atau seperenam dari total populasi. Namun begitu, bagian yang paling menarik bukanlah ukuran atau kontribusinya terhadap perekonomian melainkan potensi pertumbuhannya. Industri ini telah berhasil terus tumbuh sejak tahun 2001, termasuk selama krisis keuangan global pada 2008-2009. Saat ini, industri pulp dan kertas menghadapi tekanantekanan tambahan selain mekanisme perlindungan yang umum diberlakukan oleh pemerintah Negara tujuan ekspor, dari kalangan bisnis dan juga kelompok-kelompok kepentingan lainnya yang bahkan setelah perusahaan telah memenuhi peraturan dan memberikan kontribusi kepada masyarakat, tekanan tersebut telah menyebabkan efek merugikan: reputasi menjadi buruk, penjualan berkurang dan akhirnya menurunkan daya saing. Penelitian sebelumnya telah menunjukkan bahwa upaya mengkominikasikan tanggung jawab perusahaan dapat menciptakan nilai dan meningkatkan daya saing. Dari 94 perusahaan pulp dan kertas, hanya 21 perusahaan yang melakukan berkomunikasi dan hanya 5 perusahaan yang benar-benar menerbitkannya dalam bentuk laporan. Penelitian ini bertujuan untuk mengetahui proses penciptaan nilai yang diperoleh melalui berkomunikasi tanggung jawab perusahaan melalui dua pertanyaan penelitian utama pada bagaimana perusahaan-perusahaan mendefinisikan tanggung jawab perusahaan dan bagaimana mereka mengembangkan dan mengkomunikasikan tanggung jawab perusahaan mereka.
\end{abstract}

Kata kunci: tanggung jawab perusahaan, komunikasi, pulp dan kertas, Indonesia

\begin{abstract}
Forest product industry of Indonesia is dominated by pulp and paper with $60 \%$ of the total output, US\$ 7 billion worth of export in 2010 that translates into 4\% of the nation's export and providing livelihood for 15 million people or one sixth of the total population. The most interesting part however, is not the size or its contribution to the economy but rather its strong potential of growth. The industry has managed to keep on growing since 2001, including during global financial crises in 2008-2009. Recently however, the industry is facing additional pressures in addition to common measure imposed by governments, businesses and interest groups which even after a company has complied with regulations and contributed to the society, such pressures have caused detrimental effects: reputation gone badly, sales dwindling and eventually reduced competitiveness. Previous research had shown that communicating corporate responsibility efforts can create value and increase competitiveness, however from 94 pulp and paper companies within the industry $21 \mathrm{did}$ communicate and only 5 who actually published a report. This research aimed to investigate the value creation process which gained through communicating corporate responsibility and addressed two main research questions on how do those companies define corporate responsibility and how do they develop and communicate their corporate responsibility.
\end{abstract}

Keywords: corporate responsibility, communication, pulp and paper, Indonesia 


\section{INTRODUCTION}

Half of the world's forests concentrated in only five countries, among those are located in Indonesia and is a home to most diverse rainforest species and richest biodiversity in the region (Statistics Indonesia, 2011). According to the Ministry of Forestry, of the total land area, there is 120.35 million hectare of forest land that is under government control which among those 43.95 million ha is production forest which provides various forestry products. The top four forestry products are wood working, rattan, furniture and pulp and paper with the later dominates the entire sector by contributing more than $60 \%$ of the total output (Chrystanto and Justianto, n.d.).

The importance of pulp and paper industry also shown through its contribution toward the total export of Indonesia, contributing more than US\$ 7 billion worth of export in 2010 which translates into $4 \%$ of the nation's export and providing livelihood for 15 million people or one sixth of the total population (ITS Global, 2011). The most interesting part however, is not about the size of the industry or its contribution to the economy but rather its resilience and strong potential of growth. A statistic provided by Indonesian Pulp and Paper Association (IPPA) in 2011 indicated that the industry has managed to keep growing since 2001, including during global financial crises in 2008-2009.

Considering such a significant contribution it is one of the nation's economic interests to keep the industry growing. One way of doing so as stated by (Barney and Hesterly, 2010) is by staying competitive which can be achieved through maintaining leadership in four sources of competitiveness as follows:

a. cost,

b. access both to market and financing,

c. brand and

d. legitimacy

From the point of view of the cost structure in producing pulp and paper products Indonesia has shorter pulp wood rotation time, hence cheaper fiber price; cheap labor; relatively low energy cost and proximity to growing markets, all of those have given a huge cost advantage which most pulp and paper producer in other country could never have. However, leadership in cost alone will not be sufficient in keeping the industry competitive.
Pulp and paper industry in Indonesia also need to secure its sources to other three factors that determine competitiveness. While doing so the industry is being faced with pressures which came in various forms such as tax subsidy that reduces cost advantages, certification scheme that practically barred access to certain markets, advertisement campaign, boycott and sanctions which challenge the legitimacy of certain companies to operate. The sources of those pressures primarily come from three actors namely governments, businesses and nongovernmental organizations.

This research focuses on pressures from nongovernmental organizations in a form of advocacy efforts. In the field of international political economy, the central arena for policymaking, hence intergovernmental regimes have been traditionally the government (Sasser, et al., 2006). Thus, the NGO advocacy traditionally focused to the government. However, globalization and the availability and flow of information have changed the dynamics as now NGOs are capable of gather and spread information related to actor that actually doing work on the ground of whatever thematic issue the NGO is advocating, which is business sector which resulting in NGOs not only trying to influence governments but also put direct pressures towards companies directly (Wendelspiess, 2010). The public as well as politics which are all businesses' stakeholders have become receptive of such information (Vogel, 1996). Those stakeholders, including customers, are all interested in a range of corporate issues, sometimes product-related and sometimes related to the policies, procedures and values of the organization itself (Fill, 2009). The advocacy campaign of NGO that once provided a powerful remedy to many injustices (Stroup and Murdie, 2012) have become a recognizable role as forces that in principle have the capacity to influence the company's public perception, the political arena and therewith the company's business scope (Vogel, 1996). One of the most famous examples is the Nestle boycott due to conflicting infant formula marketing methods which led to the WHO implementing a code of marketing for breast milk substitutes. The more recent example in forestry field would be NGOs pressures towards forestry industry sector in North America in early 2000's as an attempt to urge them joining the FSC. In their battles against companies, NGOs mobilize the market which includes not just the consumers 
but also stakeholders involved in financial and factor markets. Their strategy aimed to threaten companies' profits and market shares. Companies may feel extra pressure to participate in private regime (such as the FSC certification) to solidify their reputation if profits are low and competition is high, even if this mean using resources that they barely able to afford (Sasser et al., 2006). These examples demonstrate how corporations around the globe are increasingly under fire. Therefore, the question is rather when companies will face a conflict with society in general of with NGOs in particular than whether or not they will ever face one.

Usually, NGO pressures come accompanied by media campaign which then responded by the firm. The responses towards the pressures are varied and could span across social, environmental and economic aspects of the company. Those responses are seen under the framework of corporate responsibility. This cover anything under companies' fundamental responsibility to produce an acceptable return on its owners' investment, legal responsibility to act within the legal framework drawn up by the government and judiciary, ethical responsibility to do no harm to its stakeholders and within its operating environment and finally a discretionary responsibility, which represent more proactive strategic behaviors that can benefit the firm and society (Carrol, 1991 in (Werther and Chandler, 2006). Manifestation of corporate responsibility efforts are manifested in companies' infrastructure (e.g. financial reporting practices, transparency or government practices); procurement (e.g. fair trade, uses of banned inputs etc.); operation (e.g. emission and waste, biodiversity and ecological impacts and energy efficiency) etc. Corporate responsibility can also mean an integral element of the company's strategy - the way the company goes about delivering its products or services to markets - it is also a way of maintaining the legitimacy of its actions in the larger society by bringing stakeholder concerns to the foreground (Werther and Chandler, 2006).

This paper examines the dynamics between NGO pressures and firm responses using the corporate responsibility framework. Emphasis is put on how domestic context (such as local certification regime, government attitude toward the industry, market preference) influence the dynamics. It is set out to investigate the advocacy-response process. Furthermore, it aims to first, get a better understanding on how advocacy campaign from NGOs can particularly influence their business scope of the growing pulp and paper industry in Indonesia; and second, providing example of the impact of advocacy campaign on the major players within the industry and the way they react upon the pressure they received considering domestic environmental governance regime in Indonesia. The underlying research questions raised are: What are the motives behind nongovernmental organization pressures towards Indonesian forestry sector in the last decade? How do forest product companies in Indonesia interpret and communicate corporate responsibility? And how would NGO pressures affecting company's corporate responsibility communication?

The hypothesis of the research is that Indonesian forestry companies which have been directly targeted by NGOs regarding to their forestry practices are likely to communicate their $\mathrm{CR}$ in accordance to the demands of NGOs.

\section{METHODS}

In this research the concept of what corporate responsibility means to companies and their communication are assumed to exist as a social construction. The reality is thus regarded as consisting of a number of overlapping parts for an inclusive group of people within a company, organization or an entire society. Such approach as explained by (Arbnor and Bjerke, 1997) is known as an actor approach.

Considering the importance of actors in defining the concept, this research consists of two steps. The first is collection of secondary sources of data which can be corporate responsibility report, companies' website and literature review. The second is primary source from semi structured interview.

Interviews were chosen for gathering information because of their flexibility that makes them more appropriate for exploring complex situations. Open-ended questions used enabled complex concept to be better explained and expanded during the interview according to the receipt and response of the interviewee (Bryman and Bell, 2011), thus ensuring the collection of in-depth information. 


\section{RESULTS AND DISCUSSION}

Among 85 studied pulp and paper companies, five are public companies, and $30 \%$ of the total production capacity is controlled by the top 3 companies or group of companies. Among them only 21 who actually communicate their corporate responsibility initiatives through various forms, be it traditional channel such as company websites, fliers, fact sheets or a more non-conventional channel such as social media tools. Furthermore among the 21 companies who communicate their reports, only four have their reports published on their company websites.

Since the era of globalizations NGOs have been engaging in such a web of global relation, including participation in diplomacy in which government considered to have lost their political independence. Now NGOs affects politics not only by influencing governmental structures (such as lobbying the congress or intergovernmental processes) but also by establishing private authority institutions and persuading companies to adopt them (Sasser et al., 2006).

NGOs' in their efforts in shaping companies policy has traditionally done through public politics. In addition to that NGOs seek to put pressure on companies via different types of private politics. According to the work by (Baron, 2003) there are three way NGOs deliver their pressures towards companies:

1. Direct targeting where NGOs directly target one particular company; 2. Indirect targeting where advocacy campaigns are more generalized against all companies, or a large group of companies within an industry; 3. Supply chain targeting which designed to bring pressure to bear on a firm based on tactics aimed at a company's producers or consumers; usually such campaigns focus on retailers or big name manufacturers at the downstream end of the supply chain

Two NGOs became the main focus in this research is the World Wildlife Fund (WWF)

Table 1. Comparative Table

\begin{tabular}{|c|c|c|c|}
\hline & APP & Tetra Pak & Fajar Paper \\
\hline $\begin{array}{l}\text { How the studied } \\
\text { companies } \\
\text { communicate CR }\end{array}$ & $\begin{array}{l}\text { Publishes Sustainability } \\
\text { reports } \\
\text { Emphasize on } \\
\text { sustainability, environment, } \\
\text { community development on } \\
\text { their CR communications } \\
\text { Aggressive media } \\
\text { engagement, Has used } \\
\text { the most channels to date, } \\
\text { (websites, blogs, twitter, } \\
\text { PR service) }\end{array}$ & $\begin{array}{l}\text { Publishes both } \\
\text { sustainability and CSR } \\
\text { reports } \\
\text { Emphasize on } \\
\text { sustainability, } \\
\text { environment, community } \\
\text { development on their CR } \\
\text { communications }\end{array}$ & $\begin{array}{l}\text { Publish Annual Report, } \\
\text { mostly on financial } \\
\text { with chapter on clean } \\
\text { production process and a } \\
\text { small section on CSR } \\
\text { Promotes their } 100 \% \\
\text { recycled raw material and } \\
\text { FSC certification as their } \\
\text { marketing tool }\end{array}$ \\
\hline $\begin{array}{l}\text { How the studied } \\
\text { companies } \\
\text { implement CR }\end{array}$ & $\begin{array}{l}\text { Has Sustainability and } \\
\text { Stakeholder engagement } \\
\text { department, led by a } \\
\text { director }\end{array}$ & $\begin{array}{l}\text { Has Sustainability } \\
\text { Department led by a } \\
\text { Director }\end{array}$ & $\begin{array}{l}\text { No dedicated CR related } \\
\text { department, report } \\
\text { produced by accounting } \\
\text { department }\end{array}$ \\
\hline $\begin{array}{l}\text { How the studied } \\
\text { companies } \\
\text { interpret CR }\end{array}$ & $\begin{array}{l}\text { APP consider Social } \\
\text { Responsibility programs } \\
\text { as a mean of addressing } \\
\text { economic, social and } \\
\text { environmental issues of its } \\
\text { stakeholders }\end{array}$ & $\begin{array}{l}\text { They try avoiding the } \\
\text { term CSR to avoid being } \\
\text { seen as simply following } \\
\text { trends. Sustainability } \\
\text { has been our core } \\
\text { business concept since } \\
\text { the establishment of the } \\
\text { company. }\end{array}$ & $\begin{array}{l}\text { Their corporate } \\
\text { responsibility initiatives } \\
\text { are focused on the } \\
\text { community surrounding } \\
\text { the mills }\end{array}$ \\
\hline
\end{tabular}


and Greenpeace. The Two has been conducting advocacy campaign against pulp and paper industry in Indonesia, mostly through direct and supply-chain targeting. From the reports the published, the demand was for the APP to join the FSC, a private authority regime they created which is now supported by a variety of transnational NGOs (Sasser et al., 2006). Unlike Fajar Paper and Tetra Pak, instead of joining the FSC, they opt to seek security from government regulations through various lobbying. The result, rather that joining NGO's supported regime they join the SVLK which is Indonesia's new Wood Legality Verification System.

Furthermore reflecting from historically hostile relationship between forestry firms and NGOs, APP may have believed that joining the FSC would make them vulnerable to NGO opportunism. They rather lean toward government. This is consistent with what happened to the American forest products industry in early 2000 where instead of opted to join the FSC, the forest products association created its own initiatives called Sustainable Forestry Initiatives. They at that time however did not seek security via more stringent government regulation because most land use practices in the US. Are regulated at the state level and lobbying on a state-by-state basis is costly. Contrasting with Indonesia's setting where large scale land uses practice are regulated at the national level through the ministry of Forestry.

\section{CONCLUSION}

The analysis shows that there are three different corporate responsibility definition regimes that being deployed and companies in the same tier do not necessarily use similar regime. Furthermore, among all companies being studied 21 did communicate their CR and from those, 5 companies had their $\mathrm{CR}$ related report published. There is also a trend observed that Indonesian forestry company under direct targeting do communicate their $\mathrm{CR}$ corresponding to the theme that NGO's demand such as certification scheme, forest management and community development although not necessarily opted to adopt the NGO specific demands (e.g. FSC Certification). While companies experiencing less pressure are rather communicate a more industry-friendly alternative of CR works (e.g. cross-industry certification such as ISO 14001, ISO 26000 etc.).

\section{REFERENCES}

Arbnor, I. \& Bjerke, B., 1997. Methodology for Creating Business Knowledge. 2nd ed. Lund: Sage Publications.

Barney , J. B., Hesterly, W. S., 2010. Strategic Management and Competitive Advantage: Concept and Cases. Upper Saddle River, N.J.: Prentice Hall.

Baron, D., 2003. Private Politics. Journal of Economics \& Management Strategy, Issue 12, pp. 31-66.

Bryman, A. \& Bell, E., 2011. Business research methods. 3rd ed. New York: Oxford University Press.

Chrystanto, S. Y. \& Justianto, A., 2010. National Forest Policy Review, Jakarta: Ministry of Forestry.

Fill, C., 2009. Marketing Communications: Interactivity, Communities and Content. 5th ed. Essex: Prentice Hall.

Indonesian Pulp and Paper Association, 2011. Indonesia Pulp and Paper Directory.

ITS Global, 2011. The Economic Contribution of Indonesia's Forest-Based Industries. http://www.itsglobal.net/sites/default/ files/itsglobal/ITS Indoforest Economic Report.pdf

Sasser, E. N., Prakash, A., Cashore, B., Auld, G., 2006. Direct Targetting as an NGO Political Strategy. The Berkeley Electronic Press.

Stroup, S. S., Murdie, A., 2012. There's no place like home: Explaining international NGO advocacy. Review of International Organization, Volume 7, pp. 425-448.

Vogel, D. (1996). The Study of Business and Politics. California Management Review 38 (3), 146-65.

Wendelspiess, R., 2010. Firm Response to Advocacy Campaigns - A Case Study into How Campaigns Stimulate Organizational Change. Norderstedt: Books on Demand $\mathrm{GmbH}$.

Werther, JR., W. B. \& Chandler, D. B., 2006. Strategic Corporate Social Responsibility: Stakeholders in a Global Environment. s.1.:SAGE Publication, Inc.. 
Lurnal Selulosa, Vol. 3, No. 1, Juni 2013: 9 - 13 